\title{
Research on the Inheritance of Digital Education of Mongolian Heroic Epics from the Perspective of Path Dependence Theory
}

\author{
Ying Bao \\ Xi'an University of Technology \\ Xi'an, China
}

\begin{abstract}
The path dependence theory emphasizes the understanding of the dynamic process of historical changes and the important role of accidental factors in path creation. This view provides theoretical guidance for the study of the educational inheritance of Mongolian heroic epic. The Mongolian heroic epic is the cultural accumulation achievement which reflects the national history and the national spirit. And it has formed the multi-value to promote the national unity and the development in its historical evolution and the education inheritance. In order to meet the needs of modern social development, inherit national culture and national spirit, we should change the original form of inheritance, realize the innovation of the way of education inheritance, apply the big data platform of multi-culture to serve modern education, and open a new path for the education inheritance of national culture.
\end{abstract}

Keywords-the Mongolian nationality; heroic epic; path dependence theory; inheritance of education

\section{INTRODUCTION}

The Nobel economics laureate Douglas C. North brought "path dependence" into the analysis of institutional change. And it formed the famous "path dependence theory", which caused great attention and discussion among scholars. The scholars have made discussion from the institutional evolution, social history, regional development and other multi-angles and multi-levels. In order to inherit the national spirit and promote the development of culture, we will use the theory of path dependence to analyze the Mongolian heroic epic, which is the treasure of grassland culture. And the author would explore new positioning, and discuss the value, feasibility and development path of education inheritance.

\section{ACADEMIC PROPOSITION: MAIN VIEWPOINTS AND RESEARCH PROGRESS OF PATH DEPENDENCE THEORY}

\section{A. Main Viewpoints of Path Dependence Theory}

Path dependence theory emphasizes that time and history play an important role in the analysis of social evolution process. And it has become an important paradigm for social scientists to understand social status and changes through history. In the field of social science, scholars of different disciplines have different understanding of path dependence theory.

Sewell (1996) pointed out that the path dependence theory emphasized the role of historical development. And the first occurrence of events would have certain impact on the results of the subsequent events. [1] North (1997) believes that path dependence refers to the situation in which the institutional framework shapes various choices and constrains the institutional path that may be locked down. [1] When the development goes into a certain orbit, the external organization of the system and the subjectivism model derived from the problems associated with it in the course of history would enhance this process. The formation of path dependence is not only caused by historical accidents or small events, but also by the limited rationality of actors and the transaction cost of institutional transformation. It is restricted by the interaction of economy, politics and cultural heritage. Pierson (2000) emphasizes that path dependence is a historical or event process characterized by selfreinforcement of event order. [1] Sydow (2005) proposes that path dependence is a continuous process. With the action of positive feedback mechanism, it would enter selfreinforcing lock-in stage from accidental factors, personal factors and local exploration. [1] Vergne \& Durand (2010) define path dependence in a narrow sense, arguing that path dependence includes random processes obtained under the conditions of accidental events and self-reinforcement and the possessions that lead to lock-in without external shocks. [2]

The scholars have different understanding of path dependence. However, they can also draw some common understanding. First, path dependence is not only a random dynamic process, but also a self-reinforcing lock-in state. Second, the path dependence theory emphasizes the influence of the time factor in the changes of system. Especially, it should pay attention to the historical "lag" function. This kind of lag may be decided by the historical nature. It may also be the result of the historical event. Third, path dependence claims that the early accidental historical events will have an impact on the trajectory of the development of the system. Fourth, the path dependence of history and the independence of history exist at the same time. And the two complement each other. 


\section{B. New Progress in the Study of Path Dependence Theory}

Path dependence theory is widely used in economics, politics, sociology and other fields. In recent years, with the deepening and expansion of research, scholars have gradually realized that path dependence is not only a problem of mutual dependence between technology and systems, but also a phenomenon of social cognition. Some scholars have introduced the cognitive structure of psychology into the study of institutional changes. And they believe that path dependence represents cognitive structure, social connections, and behavioral habits built on the basis of specific institutions. [3] Therefore, the discussion of cognitive limitations has become a new trend in the interdisciplinary study of path dependence theory from the perspective of social psychology. Some scholars believe that the traditional path dependence theory ignores the active role of the subjective initiative of the actors in the process of path development. And they propose that human factors should be included in the process of path development. Also, it should strengthen the research of endogenous path creation. The concept of path creation was proposed by Garudd \& Karoe (2001). They introduced the idea of "creative destruction" into the study of path creation. And they think that path creation is a conscious deviating process of actors, who need to break away from the embedded structure to create a new path. [4] Sydow (2005) puts forward "path construction" on this basis, and divides it into three stages: path generation, path persistence and path termination. Any stage is a dialectical unity process of path natural development and subjective initiative of actors. [5] The idea of path creation and path construction is the supplement to the traditional path dependence theory. And it is valuable breakthrough for the better development of path dependence theory.

As a living culture of national history and national spirit, Mongolian heroic epic is in the plight of serious loss of singing text. And it lacks young heirs. Also, it would be affected by the impact of multiculturalism. The inheritance and development of Mongolian heroic epic is facing severe challenges. We should study to guide the Mongolian heroic epic to play its cultural and educational functions with the path dependence theory and its new achievements. It would show the universality, and reflect the value of the new era. It is worthy of in-depth discussion.

\section{HISTORICAL EVOLUTION: EVOLUTION AND INHERITANCE OF MONGOLIAN HERO EPIC}

From the view of path dependence theory, ethnic minority culture is in the dynamic development process. The cultural thought is in the same vein. The accumulated essence of thought can provide us with a clue of historical changes. The Mongolian heroic epic in China is primitive literary genre based on the mythology, the story of heroes and the poems of Shaman. The historical evolution of Mongolian heroic epic is divided into the following stages according to the generation, content, plot structure of Mongolian heroic epic and the basic types of the epic put forward by Professor Renqin Daoerji.

\section{A. Initial Stage: Mono-type Mongolian Hero Epic in Pre- class Era}

The heroic epic originated in the period of the disintegration of the primitive society. And there were frequent wars among the clans and tribes in the "Hero Age". Hero epic is not only the product of people's consciousness activities in this period, but also the art form in the formation of the Mongolian nationality. The hero epic of this period is mono-type epic. It is the first, the simplest, the most basic type of the Mongolian epic. And it is the basis of the Mongolian hero epic. Also, it always goes throughout the development of the whole Mongolian hero epic. [6] Viewing from the current collection and study, the main content of the mono-hero epic is the struggle between human beings and nature, and the wars among the clans, and so on. This kind of epic has the consistency in the structure. First, it describes the time when the hero was born with a large number of magnificent words, praises the living environment, and describes the hero with exaggeration. Secondly, it describes the story plot. And it could be divided into lyrical and narrative types. The third is the end of the epic. At the end of the entire epic, heroes have defeated evil and the enemy. They have the victory and happiness in the end. At this time, the creation of heroic epic is based on the ancient social life and historical events, which is quite different from the historical facts. Also, it can sum up some history of social relations, cultural history and other major historical processes. It can further understand the reality of conquering the natural forces and evil forces through people's strength and wisdom.

\section{B. The Stage of Development: the Series and Compound Mongolian Heroic Epic in the Age of Class Division}

The creation of Mongolian heroic epic is in constant changes. With the progress of society and the changes of people's ideology and customs, the forms and contents of the early heroic epics have been enriched and developed in all aspects. And some new epics and new forms of epics have been formed on the basis of the original. The Mongolian heroic epic produced in this stage takes the early epic as the core, depending on the original pattern to develop forward. Its basic plot is formed by two different mono-type epic plot frames as the core. Therefore, it is called series compound epic. [6] According to the two core structures of marriage struggle motif series and battle motif series, series compound heroic epic can be divided into two basic types: marriage plus war epic and two wars epic. In addition to the above two basic types, there are also two special types of epic: family struggle heroic epic and war horse heroic epic. The family struggle epic enriches the traditional hero image, and shapes a brand-new villain. The character image is closer to reality. The war horse heroic epic is the innovation of Mongolian folk artiste's ability. And the story content is imagination and fiction. It is used to praise the saddle horse of hero. The heroic epic of this stage is more rigorous in structure and richer in content. It molded the new figure image. And it would reflect the reality. Through the epic, people can further understand the social situation at that time. And it would make the further development than that of the early epic. 


\section{Prosperous Phase: the Parallel and Compound Epic of Mongolian Heroic Epic in the Period of Feudalism}

The era of feudal separatism is the peak of the development of Mongolian heroic epic. The epic shows the feudal clan struggle, national struggle and religious struggle to varying degrees. The heroic epics of this period had beautiful modifiers; rich stylized structure, rich romantic color and exaggerated artistic expression. Three long epics such as "Gesar epic", "Epic of Jangar" and "Manas epic" were formed in this period. The emergence of the long epic shows the development of the Mongolian heroic epic entering into a prosperous stage. Long epics came into being and had the development on the basis of early mono-style epics. However, because of the different social background, it will inevitably have new themes, new content, new structure and new forms of expression. And its ideological content has also undergone great changes. In addition to the war stories of the original heroes, it also advocates the ideas of national unification, people's unity and opposition to separatism.

The textual structure of long epic is composed of many poems. And each poem is formed with the frame of single epic and series complex epic as the core. Many poems are closely related to each other. And they will be composed of a story plot or heroic figures in series, forming a large-scale Mongolian heroic epic. [6] Therefore, the long heroic epic is also juxtaposition complex of independent poems, also called juxtaposition composite heroic epic. The heroic epic of this period is quite different from that of the previous two stages. Especially, it should pay attention to the change of the theme. We should understand the social and historical changes in the era of feudal separatism. At the same time, we should understand people's will of hoping peace and fighting against the war. Under the unified situation, it would build a better homeland.

\section{Inheriting Methods: Artists Heritage of Mongolian Heroic Epic}

The historical evolution of Mongolian heroic epic has gone through several complementary stages. The continuation, enrichment and development of the epic cannot be separated from its living inheritance. That is to say, it mainly spreads through the oral form and folk artists' memory. Folk artists are the creators, conservators and disseminators of Mongolian heroic epics. They traveled to sing on the vast grasslands. On the one hand, they continued the vitality of heroic epic. And then, it is preserved in the folk. On the other hand, it meets people's artistic enjoyment and enriches social life. There is a common understanding in modern academic circles that some large-scale epic poems are the result of the collective creation of artists. At first, they are scattered legends and poems produced in oral form, which are constantly enriched in the process of spreading and created through the arrangement and adaptation of the heroic epic poems endowed with the social content of the new era by talented artists. The artists all have certain cultural accomplishment, and understand the national history. In the development of Mongolian heroic epic, and the inheritance of singing skills, they use the oral teaching between master and apprentice. And some families also use oral teaching. The "father-son transmission in family education and social education, and master-apprentice" education inheritance model makes the Mongolian heroic epic to have further development. These educational inheritance patterns have played an irreplaceable role in history. And it has important significance. Nowadays, with the development of society, the progress of science and technology, the improvement of people's living standard, the enrichment of content and the renewal of ideas, the current changes have influences on the existing culture. Also, it has influences on the development of Mongolian heroic epics. The time and space of their lives have been gradually reduced. Some of them have withdrawn from people's daily life, and some have even lost the meaning of the original culture. The shortage of inheritors, the simplification of the way of inheritance, the impact of foreign culture and other issues make the inheritance of Mongolian heroic epic have difficulties. And these issues directly affect national identity, national sense of belonging and national spirit of the young generation.

\section{RATIONAL PURSUIT: MUltiple VALUES OF MONGOLIAN HEROIC EPIC ON NATIONAL DEVELOPMENT}

Path dependence theory believes that some informal constraints formed in many cultural traditions of human society will have an important impact on the choice of actors. In the process of long-term historical development, cultural knowledge has been accumulated. And it gradually infiltrated into people's daily life, internalized into people's ideology and behavior, and became the universal cultural identity of specific groups and behavior norms. This kind of cultural tradition is the product of historical precipitation, which plays an imperceptible role in the social life of the people. It has the characteristics of endogamy, stability and persistence. The Mongolian heroic epic is also the same. It is the literature embodiment of social realistic life in the process of the formation, evolution and development of Mongolian nationality. And it has reflected populace broad mind and grand ideal, entertainer's thought realm and artistic achievement, national psychological characteristic and thought essence. It has important social value and farreaching educational significance.

\section{A. The Value of the Study of National History}

The epic scholar Wa Gachak pointed out: "The images in the heroic epic don't reflect the thought and behavior of individual. It reflects the fate of the whole nation. Therefore, the heroic epic is of historical significance". [7] Mongolian heroic epic, as a historical product, witnessed the development of the nation, reflected the social life and historical events at that time, and conveyed a wealth of cultural information. It has inestimable historical value. The content of the early Mongolian heroic epic is the contradiction between man and nature and the war between clan and tribe, which reflects people's understanding and imagination of natural phenomena. And it tries to conquer the nature. People should fight against the nature. With the changes of social system, the story content of Mongolian 
heroic epic has new content in the middle and late period. And it can be divided into marriage struggle type and battle type. The Mongolian heroic epic is rich in content. The structure is huge. It reflects the social life and people's rich and colorful spiritual world in the process of the generation and development of the Mongolian nationality from different angles. It is a valuable heritage to study the history of the Mongolian nationality. It connects the past, present and future, and preserves precious historical materials for the future generations to study the history of the Mongolian nationality. And it provides indispensable spiritual nourishment for the development of the Mongolian nationality.

\section{B. Aesthetic Value of National Art}

The Mongolian heroic epic is a kind of rhythmic poem. It uses romantic technique, beautiful national language, myth, legend, hymn and other material and formula. And it is also a kind of oral literature that is reproduced through artistic imagination. Viewed from the poetic structure of heroic epic, it has bold imagination and fiction, exaggerated metaphor and modifier, rich maternal series and plot frame. And some brief prose narration is inserted in the epic to show the social reality and people's desire. Viewed from the figures in the heroic epic, through a variety of artistic expressions, the hero is a multi-directional and multi-level portrayal in the epic. He is endowed with courage, will, wisdom, force and strength. Also, he is placed in the contradiction and struggle against all the natural and social hostile forces in dangerous environment. And then, it could to show his heroic character and heroic spirit. Viewed from the singing art of heroic epic, it has its own vocals and melody rhythm, the accompaniment instruments used by the artists in the performance, the modality, the form, and the movement and so on. All the concepts are to show the epic. It is national comprehensive art. The Mongolian heroic epics are characterized by exquisite artistic expression and rich cultural connotations. It is the traditional folk-custom activity. And it is also unique national poetic art. It not only gives people the enlightenment and beauty of the United States, but also cultivates sentiment and enriches their spiritual life. It has high artistic aesthetic value.

\section{Value of National Psychological Identification}

In the process of studying epic, Finnish epic theorist Lauri Honko said: "Epic is a rich cultural storage. It has the function of expressing identification and communication. And it can be used as the sustenance of self-identification of cultural groups. Also, it can create the whole consciousness in different groups, nationalities and countries". [8] The Mongolian heroic epic is just like this. And it has the value of strengthening the ethnic consciousness, expressing the national identity and strengthening the national cohesion. It is not only the display of historical memory, but also the symbol of national culture. It tells the heroic story to the people. And it encourages today's people with the heroic spirit from generation to generation. And people have spiritual sustenance and cultural identity. Moreover, in the different types of Mongolian heroic epic, heroes represent the will of the people. And they are the collection of people's ideal. Also, they are the embodiment of the national spirit. They set strength and wisdom in one. They would fight for the tribe with strong sense of ethnic group. The Mongolian heroic epic conveys and carries the nation's spiritual outlook, emotional attitude and values. Especially, the epic has been passed on for thousands of years. And it has been integrated into the daily life of the people. It can enlighten the people, strengthen the national consciousness and sense of belonging, and build the bridge of the dialogue between the people and the national history. People would obtain the national selfidentification and national identity.

\section{The Value of National Culture and Education}

Mongolian heroic epic contains religious beliefs, folk etiquette, social ethics, moral standards and other contents of the ancient Mongolian nationality. These contents are the symbol of the nation. It is valuable cultural information. And it is not replicable and regenerative. As the intellectual achievement and spiritual wealth of the national characteristics, Mongolian heroic epic has very important educational value. Especially, the ecological ethics, moral ethics and life ethics have practical significance to contemporary education. On the one hand, the ecological ethics reflected in the epic is influenced by the religious belief. On the other hand, the natural experience accumulated by the cognitive condition at that time forms the respect and awe to the nature. And then, it would promote the harmony between the human and the nature. It is also the basic idea between the human and the ecology respected by nomadic people of the Mongolian grassland. Moral is embodied in the character of the heroes in the epic. Each hero has just, brave, optimistic, simple and kind-hearted behavior. He is the ideal personality model praised by the Mongolian people. And they are worthy of learning for future generations. The concept of life is embodied in the epic of war. Influenced by the social conditions at that time, heroes, warriors and ordinary people were ready to fight to defend their beautiful homeland and inviolable land. They were hostile to the enemy and unafraid of danger. And it would sublimate the value of life into heroism and patriotism. Also, it provides good material for the patriotism education of modern minority nationalities. The spiritual value contained in the history of Mongolian heroes is worthy of learning for future generations. It is extremely valuable educational material. Through various forms of education, the broad masses, especially the younger generation, should understand the national culture and truly feel the spiritual field of the national culture. Under the influence of the excellent culture, we can enhance the national unity consciousness, cultivate the ecological view of respecting the nature and harmonious symbiosis, internalize the moral concept full of positive energy, and shape the life view of pursuing the ideal personality.

\section{Digital Platform: PATH SELECTION FOR THE INHERITANCE AND INNOVATION OF MONGOLIAN HERO EPIC EDUCATION}

The theory of path dependence emphasizes the stability and persistence of culture. However, the progressive nature 
of cultural renewal means that the absorption of other cultures is selective. And it can't absorb all cultures effectively. By absorbing the reasonable contents and advanced parts of other cultures, the original culture would have changes and development. If the culture has changes, the original inheritance path would have the track deviation with the addition of new content. It is necessary to create new inheritance path on the basis of the original path. And then, it could adapt to the changes of the times and social development. At present, with the coming of the era of big data, the application of information technology and Internet brings a new perspective and direction for the inheritance of minority culture. We should make full use of the multiculture big data platform for the purpose of serving education. And it opens a new path for the education inheritance of minority traditional culture.

\section{A. To Establish Cultural Heritage Database and Expand School-based Curriculum Teaching Resources}

Cultural heritage database is composite information system which applies digital technology to preserve, display and disseminate cultural heritage. It has the characteristics of large storage, rich content, wide dissemination and convenient inquiry. [9] In order to establish the database of cultural heritage, we should deal with the coding, transformation, storage and reproduction of cultural information resources, and create a virtual digital environment for cultural heritage. It would promote the cultural protection and achieve the effect of cultural dissemination. The establishment of the database of cultural heritage is to display national and folk culture. And it would turn the cultural resources of the cultural heritage database into educational resources, and serve the family, community and school with its vivid presentation way. And it mainly lies in the cultural infiltration. Also, it merges into the study life of the national masses, satisfies the education demand, and relieves the education resources. More importantly, we may study the cultural heritage in the life. And we could inherit it in the study.

It is an effective teaching method to develop and set up school-based curriculum for traditional culture of ethnic minority in school education. We could establish the database of national cultural heritage, and set up schoolbased curriculum for Mongolian heroic epic. The combination is a process of promoting the common development of both sides. We could use the resources in the cultural heritage database and apply them to the teaching of school-based curriculum. It can enrich the teaching resources. And the students would feel and experience the effect of audio-visual singing which is brought by the national culture without the restriction of time and space. At the same time, in the teaching of the school-based curriculum, teachers encourage students to learn the national culture and promote the interest of the national culture. They guide students to collect, record, organize and analyze the relevant information about the national culture. And then, it can supplement the resources in the cultural heritage database. Also, it would cultivate students' ability to collect and process information. The students would acquire new knowledge.

\section{B. To Develop Open Interactive Teaching between Schools and Communities with Media Transmission Methods}

With the application of network computer, a new digital media communication method is formed, which provides a new way for the inheritance of national traditional culture. The new digital media has the characteristics of diverse ways of transmission, wide range of transmission, and fast transmission speed. The main media includes digital television, digital newspaper, touch media, mobile terminals, the Internet and so on. The use of new digital media is conducive to the traditional culture of ethnic minorities in the scope of transmission. In the way of communication, it changes from the traditional way of oral teaching to the modern way of visual virtualization. In the audience groups, it changes from the same ethnic groups to the different ethnic groups. The new digital media mode of national traditional culture is the memory of cultural protection and the booster of cultural inheritance. It can be used as an intermediary to connect schools and communities. And then, it would form an integrated mode of education. Then, it would realize the open and interactive learning of minority traditional culture.

In school, students learn Mongolian heroic epic and other traditional culture mainly through teachers' explanation. However, for the students, this way lacks intuitive feelings and cultural exploration practice. They can't have in-depth understanding of the culture and its essence. The inheritor of national culture and folk artists often take the community as the stage for cultural performances. Schools and communities are isolated from each other. They should build a cultural bridge to establish contact and prevent cultural isolation. For the dissemination and development of national traditional culture, we should use new forms of media; seek communication between schools and communities. Also, we should find mutual participation and achieve resource sharing. We should take part in the study. And the school should face the community and organize the campus activity. And then, the inheritor and the folk artiste would enter the campus to communicate with the student face to face. At the same time, we could use the mobile terminal, the Internet and other media to assist the propaganda. And we could carry on the real-time record of the activity. We could take the storage as the inheritance material. The community would face the school. The students can communicate with the inheritors, disseminators and practitioners face to face. The students could learn traditional cultural knowledge according to their own interests and individual needs. Also, they would obtain more resources and achieve good interaction. It would promote the transformation from passive imparting cultural knowledge to active interaction.

\section{To Build a Platform for Cultural Public Services and Promote the Connection between Cultural Resources and Educational Heritage}

The traditional public service platforms of cultural resources mainly include the cultural center, the library, the memorial hall, the museum and so on. With the application of digital technology, the cultural public service platform also presents the new shape, such as the digital library, the digital museum and so on. Compared with the traditional 
service platform, the new digital service platform is more open, convenient and real-time. It breaks the space-time limit, displays and disseminates culture to the greatest extent, and realizes the utilization, integration and sharing of cultural resources to the greatest extent. Whether traditional or modern cultural public service platform, they play the functions of cultural protection, cultural transmission and cultural education. And it has strong leading and driving role. Cultural public service platform is the social resources. Also, it is the main organization of social education. And it undertakes important social education responsibilities. However, the existing platforms have the problem of cultural information isolation. The cultural resources can't totally be transformed into the educational resources.

Chinese Mongolian region is rich in cultural resources. And they have distinct national characteristics. In order to develop the national culture, it is necessary to integrate the cultural information, construct the cultural service platform to serve the modern education, transform the resources and promote the cultural inheritance. On the basis of traditional service platform, the construction of national culture service platform needs to use mobile terminal internet to develop digital service platform. And it can apply digital service to school education and social education. Teachers, students and other groups can learn from time to time and use cultural resources everywhere. It is helpful to protect national culture. And it would accelerate the understanding and dissemination of culture, promote the application and inheritance of culture in education. It also contributes to the communication and interaction between national culture and other cultures. It helps to transform the isolated cultural resources into the social public learning resources. And then, it would meet the needs of educational reform for educational resources. It provides learners with the content of education. They could understand the national culture.

\section{CONCLUSION}

The Mongolian heroic epic is the cultural accumulation achievement which reflects the national history and the national spirit. It represents the artistic achievements of Mongolian folk culture, contains the philosophy, religious beliefs, ethics, customs and other aspects of the Mongolian content. It has higher literary value, precious historical value, rich educational value and assignable research value. On the choice of educational inheritance path of Mongolian heroic epic, we need the help of modern educational means. And then, it could adapt to the development of the information age. And the means include the multi-cultural resources for the purpose of serving education. Especially, with the openness, service and wisdom of big data, we should effectively promote the realization of educational platform system, service system and educational vision. And we could create an open, self-circulating and sustainable educational ecological system to promote the inheritance of national culture.

\section{REFERENCES}

[1] Cao Xuanwei, Xi Youmin, Chen Xuelian. Research on Path Dependence[J]. Comparison of Economic and Social Systems, 2008(3): 186. 曹瑄玮, 席酉民, 陈雪莲. 路径依赖研究综述 $[\mathrm{J}]$. 经济 社会体制比较, 2008(3):186

[2] Vergne\&Durand, The missing link between the theory and empirics of path dependence[J]. Journal of Management Studies,2010(4)736.

[3] Metcalfe, J S. Evolutionary economics and creative destruction[M] London: Rout ledge, 1998.

[4] Garud,Kumaraswamy\&Karnoe. Path dependence or path creation[J] Journal of Management Studies,2001(4)760.

[5] Sydow, J, Windeler, A, Lering G, et al. Path creating networks: The role of consortia in processes of path extension and creation[R]. Path Dependence and Creation Processes in the E mergence of Markets , Technologies and Institutions, 21st EGOS Colloquium, June30- July 2, 2005, Berlin

[6] Rinchen Dorji. Research on the types of Mongolian epic[J]. Nationa Literature Studies, 1989(4):98. 仁钦道尔吉.关于蒙古史诗的类型研 究 [J].民族文学研究, 1989(4):98.

[7] Research Department of Chinese Folk Literature and Art Research Association. Folk Literature References (9th Series) [M]. 1964. 中国 民间文艺研究会研究部编. 民间文学参考资料(第九辑)[M]. 1964.

[8] [Finland] Lauri Honko, translated by Meng Huiying. Epic and identity expression[J]. National Literature Studies, 2001(2):89. (芬兰) 劳里. 航柯, 孟慧英译. 史诗与认同表达 [J]. 民族文学研究, 2001(2):89

[9] Luo Jianghua. On the construction of cultural heritage database and the strategy of transformation into educational resources [J]. Guizhou Ethnic Studies, 2011(6): 142. 罗江华. 论文化遗产数据库的构建及 转化为教育资源的策略 [J]. 贵州民族研究, 2011(6): 142 . 